\title{
The Cow and the Goat Descend the Mountain: Fighting Modernity with Poems
}

\section{Ivan Franceschini}

A few years ago-it must have been towards the end of 2010-a big crowd had gathered in a loft in the Centre of Contemporary Arts in Shenzhen to enjoy the music of blind folk singer Zhou Yunpeng, an artist famous for his socially committed songs on issues such as child abuse, unemployment, sky-rocketing housing costs, and much more. Halfway through the concert, Zhou announced: 'Contemporaneity is helpless, antiquity will now make its entrance.' Then time seemed to stop, while a flow of words from poets of different ages and places started chasing each other, softly accompanied by the music of Zhou's guitar. Voices from the Tang era engaged in a lively conversation with bards from the Song and Qing ages. People who lived centuries apart borrowed Zhou's voice to express exactly the same feeling: an acute longing for their families and their hometowns.

Zhou was performing songs from his then recently-released album, The Cow and the Goat Descend the Mountain (niuyang xiashan), a collection of ancient Chinese poetry set to music which appeals to a dimension of human life that transcends time and space. Listening to the lines of $\mathrm{Du} \mathrm{Fu}(712-770)$ 'it is almost as hard for friends to meet as for the morning and evening stars' (ren sheng bu xiang jian, dong ru shen yu shang), or to Meng Jiao (751-814) lyrically describing how 'the thread in the hands of a fond-hearted mother makes clothes for the body of her wayward boy; carefully she sews and thoroughly she mends, dreading the delays that will keep him late from home' (ci mu shou zhong xian, you zi shen shang yi; lin xing mi mi feng, yi kong chi chi gui),

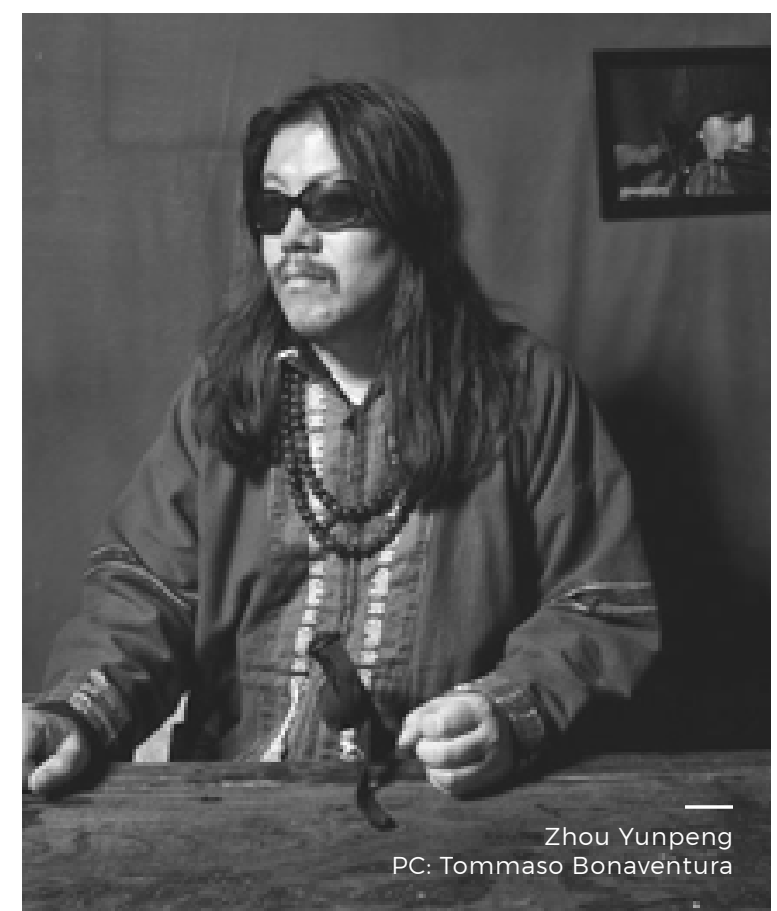

it is easy to forget that such words were written centuries ago. The same happens with Li Bai (701-762) and his poem 'The Moon over the Fortified Pass' (guanshanyue), which recounts how soldiers marching through the Jade Gate under the moonlight 'turn round, looking toward the border, and think of home, with wistful eyes and of those tonight in the upper chambers who toss and sigh and cannot rest' (shu ke wang bian se, si gui duo ku yan; lou dang ci ye, tan xi wei ying xian), or with the soldier in a poem by Nalan Xingde's (1655-1685), who dreams of his peaceful home while encamped on a river bank during a snowstorm.

\section{Two Faces of Nostalgia}

The recurrence of these feelings of detachment and homesickness all through 
Niuyang xiashan is unsurprising, since nostalgia is everywhere to be found in Chinese traditional poetry. As James Liu explained in The Art of Chinese Poetry, Chinese poets seem to be perpetually bewailing their exile and longing to return home, a feature that he attributes to

the vastness of China, the difficulties of communication that existed, the sharp contrast between the highly cultured life in the main cities and the harsh conditions in the remoter regions of the country, and the importance of the family in traditional Chinese society with the consequent deep attachment to the ancestral home. Moreover, being an agricultural people and a nation of landlubbers, the Chinese as a whole are noticeably lacking in Wanderlust.

But why sing these poems today, when distances in China, as elsewhere, have been dramatically shortened by improved communications? The simple answer is that this nostalgia is now more present than ever in the life of the Chinese people. Today's China is still a country of people on the move. Farmers leave the countryside to look for jobs in urban areas, students move to bigger cities to gain access to a better education, merchants travel from town to town to pursue their businesses. Families often have no other choice than to split up: rural mothers leave their children behind in the villages-husbands, wives and sons live and work in completely different places. Most of them meet no more than once a year, during the Spring Festival. Once they were soldiers and exiled poets, now they are migrant workers, students, and businessmen. Their existence may appear less poetic, but the underlying feelings do not seem to have changed.

Chinese language has two different words to express the concept of "nostalgia': on the one hand, huaijiu, literally 'embracing the old'; on the other, sixiang, 'homesickness'. Yet, as Niuyang xiashan clearly demonstrates, these expressions are both sides of the same coin. Singing those ancient poems, Zhou Yunpeng recounts stories of a long lost bucolic idyll mixed with melancholic feelings of nostalgia for a distant hometown. The title of the album itself is an allusion that exudes sadness and nostalgia-'the cow and the goat descend the mountain' paraphrases a verse from 'The Gentleman Serves in the Army' (junzi yuyi), a poem in the Classic of Poetry (shijing) about the wailing wife of a soldier far away from home. In the evening, the family's chickens are back in the henhouse, a yellow dog is sitting on the doorstep, even the cow and goat have come down from the mountain where they were grazing, only the husband is nowhere to be seen.

\section{Reminiscences from a Golden Age}

Ancient poetry is very much alive in today's China. As Bill Porter writes in Finding Them Gone, a recent book about his pilgrimages to the graves of the greatest poets of Chinese antiquity:

The graves of the poets I'd been visiting were so different. Some were simple, some palatial, some had been plowed under by farmers, and others had been reduced to trash pits. Their poems, though, had survived. They were still fresh in the minds of cigar-smoking farmers who most likely never attended high school. The same couldn't be said for the pronouncements of the high and mighty. Poetry is transcendent. We carry it in our hearts and find it there when we have forgotten everything else.

This holds particularly true for the selection of poetry included in Niuyang xiashan. All the poems performed by Zhou on this album belong to the collective memory of the Chinese people, and they therefore strike a chord with a Chinese 
audience from all walks of life. In an interview that I had with him in April 2012, Zhou explained that all those verses are reminiscences from his own childhood in the 1970s, when he had to learn them by heart at school: 'These poems are among the most popular in China, they are like a souvenir in your backpack, an old photo. I have been in many places, I have lost many books, but these poems are always with me. When I am on the road or I am waiting for a car or a flight, I just go over them in my head. It is like a spiritual massage and in doing so my spirit becomes peaceful. I did not choose those poems, they just popped up in my mind, it was so natural.'

Zhou lost his sight when he was nine years old. In the following decades, in spite of all the hardships he was forced to endure, he became a tireless traveller and an insatiable reader. During our interview, he repeatedly used the verb 'to look' (kan) to describe his experiences on the road. Still, this 'looking' seems to go well beyond the realm of the sight he had lost, being more like an act of 'contemplation' (guanzhao). In Zhou's own words: 'Contemplating is more than looking, it means experiencing something with all your body and mind, with the optic nerve of your soul.' Zhou believes that poetry has a fundamental role in this kind of contemplation: 'Ancient poems are very visual. Every single poem has a lot of images of mountains, rivers, flowers, smokes, trees, and skies and this is very good for blind people. These verses give us another reality, a reality that can be seen through the eyes of people from other ages. Those are the skies and the water of the Tang Dynasty and through poetry we can experience that world.'

\section{An Escape from Modernity?}

After many years of producing music that dealt critically with the plights of contemporaneity, one cannot but wonder whether Niuyang xiashan represent Zhou's escape from the many hardships of contemporary society. However, this does not seem to be the case. According to Zhou, this album is not just a return to the past, since those ancient poems bear extraordinary resemblances to today's social issues. As examples, during our interview he quoted two series of poems by Du Fu: 'Three Functionaries' (san li) and 'Three Separations' (san bie). In the first series, Du Fu writes about local cadres who press-gang all the able-bodied men into the army until only an old lady remains at home, and then also force this woman to join the army as a cook. According to Zhou, this story recalls today's forced relocations. 'Three Separations' instead tells the stories of elderly people without any kind of social security, and therefore with nothing to lose. From Zhou's point of view, the similarity to the situation of many old people today is obvious.

Neither 'Three Functionaries' nor 'Three Separations' are included in Niuyang xiashan, but contemporaneity still makes a few explicit appearances in this album. The first one is in the middle of ' $\mathrm{A}$ Song of Spring' (chunge), a composition that contains lines from three different poems by Wumen Shenshi (1183-1260) and Liu Yuxi (772-842). After sketching a series of bucolic images, Zhou starts telling the story of Li Bai, who reportedly one day saved his friend Wang Lun from drowning in a river. All of a sudden, in the middle of the song, Zhou Yunpeng directly addresses Li Bai: 'Comrade Li Bai, being an old Communist Party member from the Tang dynasty, what were you thinking when you dived into the water to save Wang Lun?' And Li Bai answers with nonchalance, mixing plain language with pompous lines from one of his most famous poems: 'Ah, purple mists rose from the Incense Peak in the sun, that day it was very hot; cascading from atop three thousand feet adown, I went to the 
river to bathe. While I was in the water I picked up Wang Lun.' With this joke, originally inspired by a child he once met, Zhou candidly mocks the Party propaganda about Lei Feng and other 'miraculous' model workers.

The second appearance of the modern age occurs in the last song, 'Love Without Speaking' (bu hui shuo hua de aiqing). This song, the only one on the album entirely written by Zhou Yunpeng, opens with a couple of verses of ancient flavour-'You are tired of doing your embroidery, even the cow and the goat have come down from the mountain' (xiu hua xiu de lei le $b a$, niu yang ye xia shang lo)-then plunges into a love story full of hatred and regret. Zhou is particularly proud of this song, which he deems the best work he has ever done:

'Love Without Speaking' is not a kind of pastoral sadness; it is a story of urban anxiety, that kind of anxiety, struggle, and hate that prominently feature in the life of people today, in a world dominated by material desires. I think that a love without hate would be incomplete. This is not only a love song, it is more a song about life in general. For instance, you can, at the same time, love and hate Beijing: your relationship with a place, a person, a time always has this kind of mixture of love and hate.

\section{Ancient Poetry as Resistance}

And love and hate are what Zhou Yunpeng feels toward this age, with all its progress in the field of communications, which have weakened the bond between people and their homes; with the rapid expansion of the Internet, which has destroyed the pleasure of writing letters and appreciating the relationships with far away friends; and with the systematic destruction of significant parts of China's cultural heritage. In the face of all this, the choice to recover these fragments of ancient poetry and give them new life through music seems to be more an act of resistance than an escape. As Zhou puts it: 'In the contemporary world, nostalgia, distance, and homesickness are all luxuries which belong to a utopia. We can only experience them through the bodies of the people from ancient times. Their way of life has become an ideal, something that we can only find by accident but not seek out on purpose. That is the reason I love the people in Niuyang xiashan: they still can experience those feelings.'

The translations of the verses of Li Bai, Meng Jiao, and Du Fu quoted in the text are by Witter Bynner.

\section{Ivan Franceschini}

Ivan Franceschini is a Marie Curie Fellow at Ca' Foscari University of Venice and at the Australian Centre on China in the World working on a project on Chinese labour in global perspective. From 2006 to 2015 , he lived in China, where he worked as a journalist and as a consultant in the field of development cooperation. His research interests focus on Chinese labour and civil society. 